\title{
OS PRINCÍPIOS DO COMUNISMO EM ENGELS (1847): APONTAMENTOS TEÓRICO- METODOLÓGICOS PARA ALÉM DO MANIFESTO COMUNISTA
}

\author{
LOS PRINCIPIOS DEL COMUNISMO EN ENGELS (1847): NOTAS TEÓRICO- \\ METODOLÓGICAS MÁS ALLÁ DEL MANIFIESTO COMUNISTA
}

\begin{abstract}
THE PRINCIPLES OF COMMUNISM IN ENGELS (1847): THEORETICALMETHODOLOGICAL NOTES BEYOND THE COMMUNIST MANIFESTO
\end{abstract}

DOI: http://dx.doi.org/10.9771/gmed.v12i3.

\author{
Raquel Sabará 1
}

\begin{abstract}
Resumo: O objetivo do artigo é trazer a relevância do texto, Princípios do Comunismo, de autoria de Engels, na formulação do Manifesto Comunista e seus apontamentos teórico-metodológicos para o além do Manifesto. O texto segue assim organizado: Alguns antecedentes históricos do texto Princípios do Comunismo e do Manifesto Comunista; Por que o Manifesto Comunista não poderia ser chamado de socialista em 1848; Princípios do Comunismo: apontamentos para além do Manifesto Comunista; A negação de Engels acerca da paternidade das ideias fundamentais contidas no Manifesto Comunista
\end{abstract}

Palavras-chave: Princípios do Comunismo; teoria-método; Manifesto Comunismo; Crítica da Economia Política

Resumen: El propósito de este artículo es llevar la relevancia del texto "Principios del Comunismo", de Engles, en la formulación del "Manifiesto Comunista" y sus puntos teóricos y metodológicos más allá del manifiesto. El texto está organizado de la siguiente manera: algunos antecedentes históricos del texto "Principios del comunismo" y "Manifiesto comunista"; la razón por la que el "Manifiesto Comunista" no podía llamarse socialista en 1848; Principios del comunismo: observaciones más allá del Manifiesto comunista; La negación de Engle de las ideas contenidas en el Manifiesto Comunista.

Palabras clave: Principios del Comunismo, teoría-método, Manifiesto Comunista, crítica a la economía política.

Abstract. The purpose of this article is to bring the relevance of the text "Principles of Communism", by Engles, in the formulation of the "Communist Manifesto" and its theoretical andmethodological points beyond the manifest. The text is organized as follows: some historical background to the text "Principles of Communism" and "Communist Manifesto"; the reason why the "Communist Manifesto" could not be called socialist in 1848; Principles of Communism: observations beyond the Communist Manifesto; Engle's denial of the ideas contained in the Communist Manifesto.

Key words: Principles of Communism, theory-method, Communist Manifesto, criticism of political economy.

\section{Introdução}

O objetivo do artigo é apresentar a relevância do texto Princípios do Comunismo, com autoria de Engels (1847), na formulação do Manifesto Comunista e em apontamentos teórico-metodológicos para o além do Manifesto. Buscar a relação entre Princípios do Comunismo com o Manifesto e com as posteriores produções de Marx além de resgatar a relevância do trabalho de Engels, é reconhecer a importância do autor tanto na construção do socialismo científico, como na teoria marxiana. 
O texto Princípios do Comunismo foi um programa de ação redigido por Engels em 1847, na forma de vinte e cinco perguntas e respostas a pedido da Liga dos Justos (GOGIOLLA, 2010). Ao contrário do Manifesto Comunista, o texto é pouco conhecido, mas de grande relevância por abordar categorias e posições teórico-políticas que seriam desenvolvidas e reorganizadas no Manifesto.

$\mathrm{Na}$ produção, Engels definiu o que seria comunismo; distinguiu proletariado de capitalista, escravo de proletário, servo de proletário, operário manufatureiro de proletário; articulou dialeticamente as consequências imediatas entre a revolução industrial e a divisão da sociedade em burgueses e proletários; trouxe o papel revolucionário da burguesia como consequência das relações de produção. Todas categorias apreendidas e fundamentadas a partir das relações sociais de produção historicamente constituídas. O autor também retratou a temporalidade imanente das relações de produção capitalistas e suas contradições sociais fundadas na natureza e nas contradições das relações burguesas o crescimento do proletariado, o grilhão das crises de superprodução e o desencontro entre a produção a apropriação capitalista. Através de apreensão científica da história, Engels articulou o desenvolvimento das relações sociais de produção ao caráter internacional da revolução e da luta de classes como permanente, não sendo possível abolir a propriedade privada de um só golpe.

Esse trabalho compartilha com a posição de Coggiola (2010, p. 26) ao afirmar que "o grande antecedente do Manifesto Comunista são os Princípios do Comunismo" e que, a partir dele, Marx e Engels elaboraram o Manifesto do Partido Comunista que foi publicado no ano seguinte, em 1848.

Assim, para voltar ao Manifesto Comunista, torna-se necessário buscar os fundamentos históricoteóricos que conformaram esse documento histórico "datado e não datado" no sentido de Gorender (1998), reconhecendo a singularidade de cada autor na produção, porém sem elevar ou descrever um autor em relação ao outro.

Muitas são as determinações histórico-teóricas que mediam a construção do Manifesto Comunista: espaço e tempo; o desenvolvimento das forças produtivas; a manifestação das contradições capitalistas; a organização nacional e internacional da classe trabalhadora frente a essas contradições; a necessidade do capital de produção e realização do valor e de controle do proletariado; a atuação política de Marx e Engels; o estágio de desenvolvimento da produção teórico-política dos dois autores etc.

A limitação deste artigo não permite aprofundar sobre todas essas determinações, mas busca resgatar um dos antecedentes histórico-teórico do Manifesto, o texto Princípios do Comunismo de autoria de Engels.

Parte-se do pressuposto de que o Manifesto, ao trazer o caráter científico da história - que a produção econômica e a estrutura social de cada época constituem a base da história política - inaugura a ação política e revolucionária da classe trabalhadora para uma participação consciente do proletariado no processo histórico da revolução social (COGGIOLA, 2010). Posteriormente, denominado de socialismo científico ou de materialismo histórico.

Em 1883, após o falecimento de Marx, Engels afirmou que a proposição fundamental do Manifesto, a concepção científica dos fatos sociais, pertence única e exclusivamente a Marx. Observa-se a partir desta ideia, que por mais que Engels tivesse afirmado a paternidade de Marx sobre essa concepção 
científica - que os fatos sociais, a história se fundamenta na estrutura econômica da sociedade burguesa as entrelinhas das vinte e cinco perguntas e repostas contidas nos Principios do Comunismo demonstram a relevância desse documento na construção de tal concepção.

O texto segue assim organizado: Alguns antecedentes históricos do texto Princípios do Comunismo e do Manifesto Comunista; Por que o Manifesto Comunista não poderia ser chamado de socialista em 1848; Princípios do Comunismo: apontamentos para além do Manifesto Comunista; A negação de Engels acerca da paternidade das ideias fundamentais contidas no Manifesto Comunista

\section{Alguns antecedentes históricos do texto Princípios do Comunismo e do Manifesto Comunista}

O texto, Princípios do Comunismo, foi elaborado em novembro de 1847, meses antes do Manifesto Comunista ser encomendado pela Liga dos Comunistas. Naquele momento, acreditava-se que a Europa estava à beira de uma revolução. A publicação do Manifesto ocorreu em março de 1848, em Londres. “[...] A urgência foi ditada pela explosão (dia 22) [de 1847] da "revolução de fevereiro" na França" (COGGIOLA, 2010, p. 9). São 172 anos desde a sua publicação.

O capitalismo estava na fase ascendente do seu desenvolvimento. Dominava o capital industrial progressista, um capitalismo de livre concorrência, anterior ao período dos monopólios. "A produção do artesanato cedia lugar à maciça produção mecânica; tombavam sob a dominação do grande capital os pequenos mestres artesãos" (CALAS, 1948, p. 5). Na França, notadamente na Inglaterra, as contradições capitalistas vierem à tona no segundo quartil do séc. XIX: desenvolvimento da indústria, crescimento da burguesia e do proletariado e simultâneas crises periódicas sacudiam o mundo capitalista (CALAS, 1948).

Entre 1846 a 1848, a Europa passava por uma crise econômica, que para Engels, caracterizava uma crise de superprodução. A catástrofe de 1846 a 1848 foi universal. "Um cataclisma econômico europeu coincidiu com a visível erosão dos antigos regimes" (COGGIOLA, 2010, p. 10).

A paz eterna prometida pelo Estado da Razão e pelos princípios de liberdade, propriedade privada e igualdade proclamados na Revolução Francesa (1789) tinham se convertido

[...] numa interminável guerra de conquistas [...] $\mathrm{O}$ antagonismo entre pobres e ricos, longe de dissolver-se no bem-estar geral [...]. A "libertação da propriedade" [...] vinha a ser para o pequeno burguês e o pequeno camponês a liberdade de vender [...] a sua pequena propriedade [...]. A ascensão da indústria converteu-se em pobreza e miséria das massas trabalhadoras [...] conflitos que eclodem não só entre as classes engendradas pela grande indústria, mas também entre as forças produtivas e as formas de distribuição por elas criadas (ENGELS, 1984, p. 33-34).

A classe trabalhadora tomava cada vez mais consciência dos seus próprios interesses. " $\mathrm{O}$ proletariado manifestou-se como uma vigora força histórica independente" (CALAS, 1948, p. 2). Em 1831, ocorreu o primeiro levante operário em Lion, na França, centro da indústria têxtil. Entre 1838 a 1842, o primeiro movimento operário nacional, o Movimento Cartista inglês, florescia. Na Alemanha, mesmo com o capitalismo no seu início, as massas operárias se organizam pelos seus interesses. Em 1844 explodiu a insurreição dos tecelões silesianos. "A primeira revolta operária na história alemã moderna, 
esmagada pela intervenção do exército prussiano." (LÖWY, 2010, p. 11). Nesse mesmo ano, Marx escreveu o artigo Glosas críticas marginais ao artigo "o rei da Prússia e a reforma social". De um prussiano.

A luta de classes entre a burguesia e o proletariado passou a ocupar o primeiro lugar na história dos países da Europa mais desenvolvidos, tomando um caráter excessivamente impetuoso e violento (CALAS, 1948).

Um espectro ronda a Europa - o espectro do comunismo. Todas as potências da velha Europa unem-se numa Santa Aliança para conjurá-lo: papa e o czar, Metternich e Guizot, os radicais da França e os policiais da Alemanha" (MARX; ENGELS, 2010, p. 39).

O comunismo já era reconhecido como uma força social e política por todas as potências da Europa.

O movimento cartista foi decisivo para surgimento do comunismo operário. Uma "enorme força social, em pleno processo de formação, não se limitava ao plano defensivo ou à atividade puramente sindical, mas também projetava na ação política” (COGGIOLA, 2010, p. 14).

Em 1782, oito homens criaram a Sociedade Correspondente de Londres. No Final do mesmo ano de criação, ela já era composta por três mil membros. Seus objetivos eram:

[...] sufrágio universal, igualdade de representação, Parlamento honesto, fim dos abusos contra os cidadãos humildes, fim das pensões outorgadas pelo Parlamento aos seus membros das classes dirigentes, menor jornada de trabalho, diminuição dos impostos e entrega das terras comunais aos camponeses (COGGIOLA, 2010, p. 14).

Os cartistas conseguiram mudanças importantes como: a primeira lei de proteção ao trabalho infantil (1833), a lei de imprensa (1836), a reforma do Código Penal (1837), a lei de supressão dos direitos sobre os cereais, a regulamentação do trabalho infantil e feminino, a lei da jornada de trabalho de 10 horas e a lei que permitia as associações políticas.

Em 1838, a Carta ou Carta do Povo, foi organizada e enviada ao parlamento inglês. Através dela, reivindicava-se:

[...] voto universal e secreto, abolição da qualificação do voto (voto por nível de renda), pagamento aos membros do Parlamento (permitindo o ingresso nele de trabalhadores), nivelação dos distritos de eleitorais, parlamentos anuais (controle mais efetivo e revogabilidade dos representantes)" (COGGIOLA, 2010, p. 15).

Neste programa democrático, o cartismo organizou movimentos de massa, e até greve geral em 1842, abarcou mais 50 mil operários, inaugurou a prática dos "piquetes móveis", depois mundialmente difundida. Em 1847, a última onda de atividade cartista conquistou a jornada de dez horas (COGGIOLA, 2010, p. 14).

Sua importância histórica consiste no lançamento e elaboração de uma base de massas à duas reivindicações centrais do operariado - a redução da jornada de trabalho e o sufrágio universal e secreto e influência na estruturação da sociedade inglesa e capitalista em geral (COGGIOLA, 2010).

Em 1838, a Carta "antecipou debates ulteriores sobre reformismo e revolução" (COGGIOLA, 2010, p. 15). Existia a ala partidária da força moral que defendia a aliança com a burguesia. Acredita-se que a pressão moral de suas reivindicações levaria o movimento à vitória. Os reformistas acreditavam que a privação de direito só seria superada "exigindo para todo o cidadão o mesmo direito em determinar a atividade do poder político" (COGGIOLA, 2010, p. 15). Reclamavam as liberdades correspondentes ao 
direito natural e não foram capazes de reivindicar para além do pensamento dos democratas burgueses radicais (COGGIOLA, 2010). Já a ala da força física defendia que só a ação direta dos operários os levaria ao triunfo. Eram responsáveis pela organização de greves.

A Liga dos Justos era, por sua vez, composta de trabalhadores sobretudo artesãos exilados em Londres, Paris e Bruxelas. Em 1843, Engels começou contatos com a Liga dos Justos. Em meados de 1847, Marx filiou-se à Liga e foram estabelecidos novos objetivos. Quando a Liga aderiu às concepções de Marx, seu slogan mudou de "Todos os Homens são livres" para "Proletários de todos os países, uni-vos!", chamada pelo Manifesto (COGGIOLA, 2010). Foi reorganizada para tornar-se democrática; buscou-se suprimir tudo o que fosse autoritário e ditatorial de direção e saiu da conspiração secreta para adotar estratégias de publicização e de propaganda pública. Essa passagem da Liga de organização secreta para as sociedades operárias comunistas públicas foi um processo histórico complexo. Foi somente nos grandes centros da Liga (Genebra, Londres, Paris) que as comunas estiveram mais contínuas, apoiando-se em associações operárias paralelas (COGGIOLA, 2010). A Liga dos Justos ou Sociedade dos Justos transformou-se na Liga dos Comunistas. Entre novembro a dezembro de 1847, suas tarefas eram: "Derrota da burguesia, dominação do proletariado, abolição da velha sociedade burguesa fundada sobre os antagonismos de classe e fundação de uma sociedade nova sem classe e sem propriedade" (CALAS, 1948, p. 6).

Antes da entrada de Marx e Engels, a Liga já tinha transitado pelo comunismo idealista dos artesãos alemães saiu de [..] um sistema utópico qualquer [aspiração utópica], por uma participação consciente no processo histórico da revolução social [...] (COGGIOLA, 2010, p. 12).

Isso só foi possível pela abstração "científica da estrutura econômica da sociedade burguesa, único fundamento teórico sólido" para substituir a aspiração de realizar "um sistema utópico qualquer, por uma participação consciente no processo histórico de revolução social [...]” (MARX apud COGGIOLA, 2010, p. 12).

A Liga dos Comunistas foi organizada democraticamente. Em novembro de 1847, por deliberação de um congresso com duração de dez dias, foi confiado a "Marx e Engels a elaboração do Manifesto e sua publicação como programa oficial da Liga dos Comunistas. O documento continha os [...] princípios que deviam levar à destruição do sistema capitalista, à edificação de um mundo novo: a Sociedade Comunista" (CALAS, 1948, p. 6).

\section{Por que o Manifesto Comunista não poderia ser chamado de socialista em 1848}

Engels, no Prefácio à edição inglesa de 1888 do Manifesto, esclareceu.

Em 1847 consideravam-se socialistas dois tipos diversos de pessoas [...] os adeptos dos vários sistemas utópicos [...] os owenistas na Inglaterra e, os fourieristas, na França, ambos reduzidos a meras seitas agonizantes [...]. De outro, vários gêneros de curandeiros sociais que queriam eliminar [...] as misérias sociais, sem tocar no capital e no lucro [Os dois grupos] não pertenciam ao movimento dos trabalhadores, preferindo apoiar-se nas “classes ocultas" (ENGELS, 2010b, p. 77. In: Prefácio à edição de inglesa de 1888). 
Em contrapartida, o setor da classe trabalhadora que exigia uma transformação radical da sociedade, convencido de que as revoluções meramente políticas eram insuficientes, denominava-se então comunista. Tratava-se ainda de um comunismo mal esboçado, instintivo e, por vezes, grosseiro [...] (ENGELS, 2010b, p. 77. In: Prefácio à edição de inglesa de 1888).

[...] o socialismo significava um movimento burguês, e o comunismo, um movimento da classe trabalhadora (ENGELS, 2010b, p. 77. In: Prefácio à edição de inglesa de 1888).

Os socialistas utópicos "se fundamentavam mais na intuição do que no estudo científico dos fatos históricos" [...] não conhecem o capitalismo senão na primeira fase de desenvolvimento" (CALAS, 1948, p. 1).

Os socialistas utópicos questionavam o sistema e elegiam o império da razão como saída para as contradições. Seus remédios "aparecia [m] como a descoberta casual de um ou outro intelecto genial" (ENGELS, 1984, p. 53). Sua missão era elaborar um sistema perfeito de sociedade. Criticava-se o modo de produção existente e suas consequências, mas não se conseguia explicá-las, muito menos destruí-lo.

Para tanto, buscava-se descobrir e implantar um novo e mais perfeito sistema de ordem. Receituários que deveriam ser testados e aperfeiçoados para servirem como modelo. Desta forma, a denominação de socialismo ser utópico, pois girava em torno da cabeça (ENGELS, 1984).

$\mathrm{Na}$ visão desses socialistas, a classe operária era incipiente e estava em formação. Incapaz de organizar-se politicamente, por isso precisava de ajuda, e esta tinha que vir de fora da classe trabalhadora (ENGELS, 1984). Ela compreendia o antagonismo das classes e a ação dissolvente dos elementos da própria sociedade. Como não via nenhum potencial revolucionário na classe trabalhadora, mas somente uma classe sofredora, punham-se na busca de uma ciência social para criar essas condições. "Procuram [...] atenuar a luta de classes e conciliar os antagonismos. Continuam a sonhar com a realização experimental de suas utopias" (MARX; ENGELS, 2010, p. 67).

Para Marx e Engels a "emancipação dos trabalhadores deve ser obra da própria classe trabalhadora" (ENGELS, 2010a, p. 79. In: Prefácio à edição de alemã de 1883), o Manifesto, portanto, foi denominado de Manifesto de Comunista.

\section{Princípios do Comunismo: apontamentos para além do Manifesto Comunista}

Já em 1847, Engels definiu o comunismo como uma “doutrina das condições de libertação do proletariado" (ENGELS, 1847, in: Princípios Básicos do Comunismo). Mas essa doutrina de libertação do proletariado, como ver-se-á à frente, não era fundada em princípios morais da razão, nem girava em torno da cabeça, no sentido idealista e utópico, mas na supressão das condições materiais que prendiam o proletário à exploração - as relações de propriedade burguesas, nelas a liberdade de mercado e de propriedade privada.

No texto, o proletariado foi definido como aquela classe dos que nada possuem "obrigados a vender o seu trabalho aos burgueses a fim de obter em troca os meios de existência necessários ao seu sustento” (ENGELS, 1847, in: Princípios Básicos do Comunismo). 
[...] classe da sociedade [após revolução industrial] que tira o seu sustento única e somente da venda do seu trabalho e não do lucro de qualquer capital; aquela classe cujo bem e cujo sofrimento, cuja vida e cuja morte, cuja total existência dependem da procura do trabalho e, portanto, da alternância dos bons e dos maus tempos para o negócio, das flutuações de uma concorrência desenfreada. [...] é a classe trabalhadora do século XIX (ENGELS, 1847, in: Princípios Básicos do Comunismo).

Nesse documento, o proletariado já era apreendido como uma categoria, numa relação de produção e apropriação, despossuído de seus meios de subsistência e obrigado a vender-se sob o jugo de

mercado de procura de trabalho por parte do capitalista. Porém, nem Engels ou Marx ainda tinham distinguido trabalho de força de trabalho². Mas Marx, em 1844, nos Manuscritos econômico-filosóficos de 1844, tinha iniciado sua reflexão sobre o salário e o ganho do capital.

Nos Manuscritos econômico-filosóficos de 1844, Marx expôs que na sociedade moderna o trabalhador [a força de trabalho] adquiriu a condição de mercadoria (coisa, valor de troca), pois "a procura de homens regula necessariamente a produção de homens assim como de qualquer outra mercadoria” (MARX, 2010c, p. 24). Por isso "a existência do trabalhador é, portanto, reduzida às mesmas condições de existência de qualquer outra mercadoria" (MARX, 2010c, p. 24). Para ele, o trabalhador [força de trabalho] tornou-se propriedade ou propriedade alheia.

Em 1844, nos Manuscritos econômico-filosóficos de 1844, Marx defendeu que para o trabalhador, o trabalho [a força de trabalho] não pode ser acumulada como qualquer outra mercadoria, ele é forçado a vendê-lo diariamente para garantir a sua reprodução social. O custo da produção do trabalhador [da força de trabalho] torna-se tão restrito chegando ao ponto de prover somente a propagação e a manutenção dos trabalhadores. O trabalhador não é livre para vender seu trabalho [sua força de trabalho], já o capitalista é livre para comprá-lo ou não. Por esses motivos, o trabalhador [a força de trabalho] torna-se uma mercadoria e a sua venda transforma-se em escravidão (MARX, 2010c).

O trabalhador se torna tão mais pobre quanto mais riqueza produz, quanto mais a sua produção aumenta em poder e extensão. O trabalhador se torna-se mercadoria tão mais barata, quanto mais mercadorias produz. Com a valorização do mundo das coisas [...] aumenta em proporção direta a desvalorização do mundo dos homens. O trabalho não produz somente mercadorias, ele produz a si mesmo e ao trabalhador como mercadoria, e na medida em que produz, de fato, mercadorias em geral (MARX, 2010c, p. 80).

Marx e Engels, no Manifesto, apontam que por meio da troca, o capital ${ }^{3}$ se apropria não do trabalhador, mas de seu trabalho. Se a oferta de força de trabalho é maior que a procura, a mercadoria força de trabalho é desvalorizada e parte dos trabalhadores cai na fome ou na miséria,

[...] constrangidos a vender-se a retalho, são mercadoria, artigo de comércio como qualquer outro artigo de comércio, em consequência estão sujeitos a todas as vicissitudes da concorrência, a todas as flutuações do mercado (MARX; ENGELS, 2010, p. 46).

Em outro momento no texto Princípios do Comunismo, para responder a questão se sempre houve proletariado, Engels mais uma vez relacionou a criação do proletariado como classe que emerge das relações de produção capitalistas. Sua resposta foi que nem sempre houve os proletários e que nem sempre a concorrência foi livre e desenfreada, mas que as classes pobres e trabalhadoras sempre existiram. 
Naquele momento Engels via a revolução industrial, nela o aumento da produtividade do trabalho, como a única causa da criação do proletariado. Conforme o autor, na segunda metade do século XVIII, após a revolução industrial, ocorreu a introdução da máquina à vapor, as máquinas de fiar e outras que

[...] transformaram todo o modo de produção anterior e suplantaram os antigos operários, na medida em que as máquinas forneciam mercadorias mais baratas e melhores do que as que os operários podiam produzir com as suas rodas de fiar e teares imperfeitos. Estas máquinas colocaram, assim, a indústria totalmente nas mãos dos grandes capitalistas e tornaram a escassa propriedade dos operários (ferramentas, teares, etc.) completamente sem valor, de tal modo que, em breve, os capitalistas tomaram tudo nas suas mãos e os operários ficaram sem nada (ENGELS, 1847, in: Princípios Básicos do Comunismo).

Apesar do texto Princípios do Comunismo ter sido escrito décadas antes dos estudos econômicos de Marx e da sua crítica da economia política mais madura, vê-se no escrito acima o caráter materialista na formação das classes sociais - burgueses e proletários; as transformações de relações não capitalistas em capitalistas; o início de uma apreensão do aumento da produtividade e da intensidade do trabalho relacionada à produção de mais valores de uso com menor valor de troca e; o processo de concentração do capital. Anos depois, a revolução industrial passou a ser vista por Marx não como a única causa da criação do proletário, mas como apenas um entre tantos processos socio-históricos, a exemplo da acumulação primitiva, da disponibilidade de capital de um lado e meios de produção de outro, e do desenvolvimento das forças produtivas com o aumento da produtividade do trabalho.

Se avançarmos mais à frente, em $O$ Capital, consta-se que no capitalismo há uma tendência de aumento da composição orgânica do capital que se expressa na substituição do trabalho vivo pelo trabalho morto. No capitalismo, os aumentos da produtividade e da intensidade do trabalho levam à diminuição do tempo socialmente necessário de produção da mercadoria e, consequentemente, à queda do seu valor. Marx também apresenta os processos de subsunção formal do trabalhador pela acumulação primitiva; pela simplificação do trabalho e divisão social do trabalho na manufatura e na indústria e, pela elevação da jornada de trabalho. Encontra-se, também, a subsunção real do trabalhador ao capital pelo aumento da produtividade e da intensidade do trabalho e a generalização do trabalho abstrato na forma de trabalho assalariado.

No texto, Princípios do Comunismo, Engels esclareceu que as antigas classes sociais (artesãos, classe média, mestres...) constituem-se em duas novas classes. Aos poucos, essas classes foram absorvidas tanto na classe dos capitalistas, quanto na classe dos trabalhadores.

No Manifesto, Marx e Engels também trouxeram o desenvolvimento da sociedade capitalista, que "caracteriza-se pela simplificação dos antagonismos de classe e a sociedade dividindo-se "cada vez mais em dois vastos campos opostos, em duas grandes classes diametralmente opostas: a burguesia e o proletariado" (MARX; ENGELS, 2010, p. 41).

No texto de 1847 de Engels, a classe capitalista foi apreendida, também, como uma categoria a partir de numa relação de produção e de apropriação, proprietária dos meios de produção e das matérias primas produtora de valores de uso necessários à existência dos indivíduos. A Classe dos grandes 
capitalistas - burgueses ou burguesia - era aquela classe que detinha "quase exclusivamente na posse de todos os meios de existência e das matérias-primas e dos instrumentos (máquinas, fábricas) necessários para a produção dos meios de existência” (ENGELS, 1847, in: Princípios Básicos do Comunismo).

Em 1844, Engels no texto Esboço de uma crítica da economia política, ao discutir custo de produção, valor e preço da mercadoria introduziu de forma germinal a discussão do trabalhador [força de trabalho] como mercadoria e seu salário regido pela guerra entre o capitalista e o trabalhador e a determinação da procura e oferta de trabalho (ENGELS, 1979) sobre seu custo de produção e seu preço de mercado. No mesmo ano, Marx, nos Manuscritos Econômico-filosóficos (MARX, 2010c) avançou na abstração do trabalhador [da força de trabalho] como mercadoria e seu salário regido pelas leis do mercado.

Em 1846, no texto, A Ideologia Alemã, Marx e Engels lançaram as bases da concepção científica da história, o materialismo histórico. Eles discutiram a produção e o intercâmbio; a divisão do trabalho e as formas de propriedade tribal, antiga e feudal; o ser social e a consciência social; as condições de libertação real do homem; a divisão social do trabalho e as consequências para a propriedade privada. Refletiram sobre o Estado e a alienação da atividade social; o desenvolvimento das forças produtivas; a transformação da história em história mundial e a necessidade de uma revolução; os instrumentos de produção e a forma de propriedade; a divisão material e intelectual do trabalho e a separação entre a cidade e o campo. Também, naquele momento, se debruçaram sobre a concorrência entre os indivíduos e a formação das classes sociais; o desenvolvimento das contradições entre as forças produtivas e a forma de intercâmbio ou apropriação; a livre concorrência; a necessidade de abolição da propriedade privada; a relação do Estado e do direito com a propriedade; as formas de consciência social entre outros (MARX; ENGELS, 2007).

Em 1847, Engels também trouxe a venda do trabalho [força de trabalho] dos operários aos burgueses como uma mercadoria regida pelas leis do mercado, sob o domínio da indústria e da livre concorrência.

O trabalho [força de trabalho] é uma mercadoria como qualquer outra, e daí que o seu preço seja determinado precisamente pelas mesmas leis que o de qualquer outra mercadoria. O preço de uma mercadoria, sob o domínio da grande indústria ou da livre concorrência - o que, como veremos, vem a dar ao mesmo -, é, porém, em média, sempre igual aos custos de produção dessa mercadoria. O preço do trabalho é, portanto, também igual aos custos de produção do trabalho. Os custos de produção do trabalho consistem, porém, precisamente, em tantos meios de existência quantos os que são necessários para manter os operários em condições de continuar a trabalhar e para não deixar extinguir-se a classe operária (ENGELS, 1847, in: Princípios Básicos do Comunismo).

Anos depois Marx chegará à conclusão de que a única mercadoria do proletário é a sua força de trabalho, enquanto trabalho vivo em ação. "No mercado, o que se contrapõe diretamente ao possuidor de dinheiro não é, na realidade, o trabalho, mas o trabalhador.” (MARX, 2013, p. 606), vendendo a sua força de trabalho. Neste sentido, ele não vende o trabalho, mas sim, sua força de trabalho.

No texto, Princípios de Comunismo, Engels também trouxe a questão sobre o valor trabalho [o valor de força de trabalho]. Entretanto, ele e Marx ainda tinham o preço do trabalho como custo do trabalhador, ou custo de produção, como os "meios de existência quantos os que são necessários para 
manter os operários em condições de continuar a trabalhar e para não deixar extinguir-se a classe operária" (ENGELS, 1847, in: Princípios Básicos do Comunismo). Nesse momento, tanto Engels como Marx, estavam ainda com a visão de Adam Smith sobre o valor do custo trabalhador ou do salário corresponder ao custo de produção do trabalhador individual no processo de produção.

Foi somente na crítica da economia política avançada - nos Grundrisse, nos Manuscritos de 1861 63 e depois em O Capital - que Marx fez (i) a abstração do mais-valor absoluto e relativo; (ii) criticou a visão sobre o valor da força de trabalho apenas como o valor de meios de produção necessários para reproduzir o trabalhador individual no processo de produção, concebendo o valor da força de trabalho como tempo socialmente necessário de reprodução da força de trabalho e; (iii) distinguiu, também, valor da força de trabalho de preço da força de trabalho.

$\mathrm{Na}$ sua teoria do valor trabalho em O Capital, Marx negou que o valor seja determinado pela quantidade de trabalho posto na produção de dada mercadoria. Defendeu o trabalho como substância social comum a todas as mercadorias. O trabalho não tem valor, pois quem se põe no mercado é o trabalhador e não o trabalho. "No mercado, o que se contrapõe diretamente ao possuidor de dinheiro não é, na realidade, o trabalho, mas o trabalhador." [...] o trabalho é substância e medida de valor imanente de valores, mas ele mesmo não tem valor nenhum (MARX, 2013, p. 607).

Para Marx, o que determina a grandeza do valor “[...] é a quantidade de trabalho socialmente necessário ou tempo de trabalho socialmente necessário para a produção de um valor de uso.” (MARX, 2013, p. 117), ou o tempo de trabalho em média necessário. ${ }^{4}$ O valor trabalho é medido em quantidades de trabalho socialmente necessário que contém a mercadoria, sendo computado em horas, dias etc. Para Marx,

[...] uma mercadoria tem valor porque é uma cristalização do trabalho social. A grandeza de seu valor, o seu valor relativo, depende da maior ou menor quantidade de substância social que ela encerra, quer dizer, da quantidade relativa de trabalho necessário para sua produção [...] o valor de uma mercadoria está para o valor de outra mercadoria, assim como a quantidade de trabalho está para quantidade de trabalho incorporado em outra (MARX, 2010 d, p. 100-101).

Dessa forma, "O valor da força de trabalho é determinado pela quantidade de trabalho socialmente necessário para sua produção.” (MARX, 2010d, p. 112) como o de outra mercadoria qualquer. $\mathrm{O}$ “[...] valor da força de trabalho é determinado pelo valor dos meios de subsistência necessários para produzir, desenvolver, manter e perpetuar a sua força de trabalho.” (MARX, 2010d, p. 112). São os meios de consumo necessários ao sustento da força de trabalho e de sua família - aqueles que irão substituí-lo no mercado, perpetuando a classe dos trabalhadores. Marx ainda afirmou que

Apesar de a forma do trabalho como trabalho assalariado ser decisiva para a configuração de todo o processo e para o modo específico da própria produção, o trabalho assalariado não é determinante de valor. Na determinação do valor, trata-se do tempo social de trabalho em geral, da quantidade de trabalho de que a sociedade costuma dispor e cuja absorção relativa pelos diferentes produtos determina, em certa medida, o respectivo peso social destes últimos. A forma específica em que o tempo social de trabalho se impõe como determinante no valor das mercadorias está, porém, vinculada à forma do trabalho como trabalho assalariado e à forma correspondente dos meios de produção como capital, na medida em que apenas sobre essa base a produção de mercadorias se converte na forma geral da produção. (MARX, 2017, p. 943-944) 
O valor não é "[...] determinado apenas pela quantidade de trabalho que lhe confere sua última forma, mas também pela massa de trabalho contida em seus meios de produção.” (MARX, 2013, p. 390). O valor é determinado pelo tempo social de trabalho em geral, ${ }^{5}$ ou seja, pela grandeza de trabalho que a sociedade dispõe na produção dos diferentes produtos. Pelo tempo socialmente necessário, o qual é absorvido em meios de produção e trabalho vivo. O valor de uma mercadoria é "[...] a forma objetiva de trabalho social gasto em ação." (MARX, 2013, p. 605). Mede-se a grandeza do valor “[...] pela grandeza de trabalho nela contida." (MARX, 2013, p. 605).

E como é possível determinar o valor, por exemplo, de uma jornada de trabalho de 12 horas? Não pelas 12 horas de trabalho nela contida. Nem pela "[...] quantidade de trabalho exigida para a produção do salário." (MARX, 2013, p. 605, nota 23). "Mas pela quantidade de trabalho vivo necessário para sua produção", (MARX,2013, p. 607) produção da mercadoria.

No texto Princípios do Comunismo, Engels trouxe também a lei econômica do salário, numa visão ainda restrita à troca e demanda, na qual o salário é regido pelos ganhos do capital: tempos melhores de acumulação, melhores salários; tempos piores de acumulação, menores salários.

Naquele momento, tanto para Engels, quanto para Marx a venda do trabalho [força de trabalho] dependia estritamente da procura de força de trabalho pelo capitalista, portanto ligada às flutuações do mercado e contradições inerentes a ele. Os autores ainda não concebiam a ideia de que a procura e a oferta de força de trabalho têm influência uma sobre a outra, pois o capital, ao mesmo tempo em que cria riqueza, também cria na mesma proporção a pobreza e com ela amplia "seu" exército industrial de reserva disponível para os momentos da procura por força de trabalho. Portanto, que a procura e a oferta de trabalho estão relacionadas também ao desenvolvimento das forças produtivas do trabalho, da produtividade e intensidade do trabalho, ou seja, pela relação entre trabalha morto e trabalho vivo.

Em 1844, no texto Esboco de uma crítica da economia politica, Engels também trouxe a dialética da luta de classes nos diferentes modos de produção. Entretanto, o autor ainda não tinha para si o processo de acumulação primitiva na formação do capitalismo liberando a força de trabalho dos meios de produção para a venda da força de trabalho como mercadoria. Foi somente em 1857, através do trabalho Formações econômicas pré-capitalistas que integra os Grundrisse, que Marx refletiu sobre os processos históricos que transformaram a força de trabalho em mercadoria:

[...] processos históricos que transformaram a massa de indivíduos em uma nação, senão em trabalhadores genuinamente livres, imediatamente, em trabalhadores potencialmente livres, cuja única propriedade seja sua força de trabalho e a possibilidade de trocá-las pelos valores existentes. Tais indivíduos confrontam todas as condições com a propriedade alheia, como sua não propriedade, ao mesmo tempo como algo intercambiável como valor e, portanto, até certo ponto, apropriada pelo trabalho vivo. Tais processos de dissolução são os seguintes: a dissolução do relacionamento servil que liga o trabalhador ao solo e ao senhor do solo mas, de fato, presume sua propriedade dos meios de subsistência (que corresponde, na verdade, a sua separação do solo); a dissolução da relações de propriedade que fazem dele um "yeoman" pequeno proprietário de terras ou arrendatário (colonus) livre e que trabalha ou um camponês livre; a dissolução das relações corporativistas que pressupõem a propriedade do trabalhador quanto aos instrumentos de produção e ao trabalho em si, como uma certa forma de capacidade artesanal não apenas como fonte de propriedade, mas como a própria propriedade; também, a dissolução das relações de clientela em 
seus diversos tipos, em que não proprietários figuram como co-consumidores do excedente de produto no séquito de seus senhores e, em troca, usam sua libré, participam de seus conflitos, realizam atos reais ou imaginários de serviço pessoal etc. (MARX, 1986, p. 97-98).

No texto de 1847, Engels, didaticamente e dialeticamente também distinguiu escravo de proletário, servo de proletário, operário manufatureiro de proletário. Todas categorias apreendidas e fundamentadas nas relações sociais de produção historicamente constituídas.

Quadro 1 - Distinção entre o escravo e o proletário

\begin{tabular}{|c|c|}
\hline ESCRAVO & PROLETÁRIO \\
\hline ANTIGUIDAE & $\begin{array}{c}\text { DESENVOLIMENTO DA MANUFATURA } \\
\text { E REVOLUÇÃO INDUSTRIAL }\end{array}$ \\
\hline $\begin{array}{l}\text { Está vendido de uma vez para sempre; } \\
\text { Coisa e não membro da sociedade cível; } \\
\text { Escravo do proprietário; } \\
\text { Tem a existência assegurada pelo senhor; } \\
\text { Está fora da concorrência; } \\
\text { Liberta-se ao abolir, de entre todas as relações de propriedade } \\
\text { privada, apenas a relação de escravatura e ao tornar-se, assim, } \\
\text { ele próprio proletário. }\end{array}$ & $\begin{array}{l}\text { Tem de se vender a si próprio diariamente e hora } \\
\text { a hora; } \\
\text { Vende o seu trabalho [força de trabalho] ao } \\
\text { capitalista; } \\
\text { Membro da sociedade civil e reconhecido como } \\
\text { pessoa; } \\
\text { Não tem a existência assegura, "só é comprado } \\
\text { quando alguém dele precisa"; } \\
\text { Está dentro da concorrência e sente todas as suas } \\
\text { flutuações; } \\
\text { A venda do trabalho [força de trabalho] depende } \\
\text { da procura de força de trabalho pelo capitalista; } \\
\text { A venda do seu trabalho [força de trabalho] está } \\
\text { sujeita ao mercado, procura por trabalho [força de } \\
\text { trabalho]; } \\
\text { O proletário só pode libertar-se ao abolir a } \\
\text { propriedade privada em geral [a forma } \\
\text { assalariamento, que esconde o trabalho não pago, } \\
\text { fundamento de toda a exploração]. }\end{array}$ \\
\hline
\end{tabular}

Fonte: ENGELS, 1847, in: Princípios do Comunismo. Elaboração própria.

Quadro 2 - Distinção ente o servo e o proletário

\begin{tabular}{|c|c|}
\hline SERVO/ARTESÃO & PROLETÁRIO \\
\hline IDADE MÉDIA E CIDADADES & CAPITALISMO \\
\hline $\begin{array}{l}\text { Os servos dos nobres proprietários de terras; } \\
\text { Os oficiais artesão à serviço de mestres pequeno-burguês; } \\
\text { Tem a posse e o usufruto de um instrumento de produção, } \\
\text { de uma porção de terra, contra a entrega de uma parte do } \\
\text { produto, ou contra a prestação de trabalho; } \\
\text { Tem uma existência assegurada; } \\
\text { Está fora da concorrência; } \\
\text { Liberta-se fugindo para as cidades e tornando-se aí artesão, } \\
\text { ou dando ao seu amo dinheiro, em vez de trabalho e } \\
\text { produtos, e tornando-se rendeiro livre, ou expulsando o } \\
\text { senhor feudal e tornando-se ele próprio proprietário: em } \\
\text { suma, entrando, de uma ou de outra maneira, na classe } \\
\text { proprietária e na concorrência. }\end{array}$ & $\begin{array}{l}\text { Trabalha com instrumentos de produção de outrem } \\
\text { por conta desse outrem, contra o recebimento de } \\
\text { uma parte do produto; } \\
\text { Não tem uma existência assegurada; } \\
\text { Está dentro da concorrência; } \\
\text { Liberta-se abolindo a concorrência, a propriedade } \\
\text { privada e todas as diferenças de classes. }\end{array}$ \\
\hline
\end{tabular}

Fonte: ENGELS, 1847, in: Princípios do Comunismo. Elaboração própria.

Quadro 3 - Distinção ente o operário manufatureiro e o proletário

\begin{tabular}{|l|l|}
\hline \multicolumn{1}{|c|}{ OPERÁRIO MANUFATUREIRO } & \multicolumn{1}{|c|}{ PROLETÁRIO } \\
\hline \multicolumn{1}{|c|}{ SEC. XVI-XVIII } & \multicolumn{1}{|c|}{ SEC. XIX } \\
\hline Quase sempre na sua posse um instrumento de produção: & Não tem nada disso; \\
o seu tear, as rodas de fiar para a família, um pequeno & $\begin{array}{l}\text { Vive, na maioria dos casos, em grandes cidades e } \\
\text { está numa pura relação de dinheiro com o seu } \\
\text { terreno que cultivava nas horas vagas; }\end{array}$ \\
$\begin{array}{l}\text { Vive quase sempre no campo e em relações mais ou menos } \\
\text { patriarcais com o seu amo ou patrão; }\end{array}$ & \\
\hline
\end{tabular}


É arrancado das suas relações patriarcais pela grande

indústria, perde a propriedade que ainda possuía e só então

se torna ele próprio proletário.

Fonte: ENGELS, 1847, in: Princípios do Comunismo. Elaboração própria.

No documento, Princípios do Comunismo, Engels também articulou dialeticamente as consequências imediatas entre a revolução industrial e a divisão da sociedade em burgueses e proletários.

Conforme Engels a revolução industrial desenvolveu em toda a parte o proletário na mesma medida em que desenvolveu a burguesia.

Quadro 4 - Revolução industrial e desenvolvimento da burguesia e do proletariado

\begin{tabular}{|l|l|}
\hline \multicolumn{1}{|c|}{ BURGUESIA } & \multicolumn{1}{|c|}{ PROLETÁRIADO } \\
\hline Se tornaram mais ricos; & Se tornaram mais numerosos; \\
Concentração de burgueses na cidade; & Concentração dos proletários nas cidades. \\
A concentração dos proletários nas cidades torna mais & \\
vantajoso explorar a indústria [oferta abundante de mão de & \\
obra barata]; & \\
A burguesia ao mesmo tempo em que produz um & \\
descontentamento crescente, cria um poder crescente do & \\
proletariado, a revolução da sociedade pelo proletariado. & \\
\hline
\end{tabular}

Fonte: ENGELS, 1847, in: Princípios do Comunismo. Elaboração própria.

Nos Princípios do Comunismo, Engels também trouxe de forma germinal a incidência do aumento da produtividade do trabalho sobre o valor da mercadoria, seu decréscimo. Conforme Engels o "trabalho manual foi completamente destruído pelo fato de os preços dos artigos industriais se tornarem cada vez mais baratos em consequência do trabalho das máquinas” (ENGELS, 1847, in: Princípios Básicos do Comunismo).

A questão do aumento da produtividade do trabalho e a diminuição do valor da mercadoria ou, do tempo de trabalho socialmente necessário, foi desenvolvida por Marx nos Grundrisse e em O Capital . Conforme Marx, o aumento da produtividade do trabalho, pelo desenvolvimento das forças produtivas, diminui o tempo socialmente necessário de produção da mercadoria, portanto seu valor, aumentando o trabalho morto e diminuindo o trabalho vivo. A consequência disso, ou sua expressão, é o crescimento da superpopulação relativa - os supranumerários para o capital - que expulsa do processo de produção passa a engrossar as franjas do exército industrial de reserva.

No Princípios do Comunismo, Engels também esclareceu sobre o papel revolucionário da burguesia como consequência inerente ao desenvolvimento das relações burguesas.

Conforme o autor, a burguesia tomou nas suas mãos o poder político e desalojou as classes até então dominantes: a aristocracia, os burgueses das corporações e a monarquia absoluta que os representava. Ela aniquilou o poder da aristocracia, da nobreza, ao abolir os morgadios ou a inalienabilidade da propriedade fundiária e todos os privilégios da nobreza. Também destruiu o poder dos burgueses das corporações, ao abolir as corporações e os privilégios dos artesãos. As relações não capitalistas foram substituídas pela livre concorrência.

A burguesia, depois de ter aniquilado por esta forma o poder social da nobreza e dos burgueses das corporações, aniquilou-lhes também o poder político. Assim como na sociedade se elevou a primeira classe, proclamou-se também como primeira classe 
politicamente. O fez com a introdução do sistema representativo, que assenta na igualdade burguesa perante a lei, no reconhecimento legal da livre concorrência, e que nos países europeus foi instaurado sob a forma da monarquia constitucional. Nestas monarquias constitucionais são apenas eleitores aqueles que possuem um certo capital, ou seja, apenas os burgueses elegem os deputados, e estes deputados burgueses, por meio do direito de recusar impostos, elegem um governo burguês (ENGELS, 1847, in: Princípios Básicos do Comunismo).

Esse papel revolucionário da burguesia foi reformulado no Manifesto.

No texto de 1847, Engels, através de apreensão científica da história, articulou o desenvolvimento das relações sociais de produção ao caráter internacional da revolução; à da luta de classes e essa como permanente e; que não seria possível abolir a propriedade privada de um só golpe.

Para o autor, todos os países que até então não se assentavam na manufatura, foram violentamente arrancados do seu isolamento e passaram a comprar as mercadorias mais baratas dos ingleses, ao ponto de arruinar os seus próprios operários manufatureiros (ENGELS, 1847, in: Princípios Básicos do Comunismo).

[...] a grande indústria colocou em relação uns com os outros todos os povos da Terra, juntou todos os pequenos mercados locais no mercado mundial, preparou, por toda a parte, o terreno para a civilização e o progresso, de modo que tudo aquilo que acontece nos países civilizados tem de repercutir-se em todos os outros países. De tal modo, que se agora em Inglaterra ou em França, os operários se libertarem, isso terá de arrastar consigo revoluções em todos os países, as quais, mais tarde ou mais cedo, conduzirão igualmente à libertação dos operários locais (ENGELS, 1847, in: Princípios Básicos do Comunismo).

Em segundo lugar, em toda a parte em que a grande indústria substituiu a manufatura, a burguesia desenvolveu, no mais alto grau, a sua riqueza e o seu poder, e tornou-se a primeira classe do país (ENGELS, 1847, in: Princípios Básicos do Comunismo).

Vejamos que no texto já está presente o germe sobre o desenvolvimento do capital como sistema internacional, a generalização planetária das relações mercantis, a internacionalização do mercado e a interdependência do sistema, bem como a internacionalização do proletariado e da luta de classes e sua libertação como processo em nível planetário. Esta questão será desenvolvida com mais profundidade no Manifesto.

Engels também introduziu de forma embrionária a temporalidade imanente das relações capitalistas e suas contradições sociais fundadas na natureza das relações sociais de produção - o crescimento do proletariado, o grilhão das crises de superprodução e o desencontro entre produção e apropriação capitalista.

[...] a concorrência e, em geral, a exploração da produção industrial por singulares se tomou para ela um grilhão que tem de quebrar e quebrará; que a grande indústria, enquanto for empreendida na base atual, somente se pode manter por meio de uma perturbação geral repetida de sete em sete anos, a qual ameaça, de cada vez, toda a civilização, e não só faz cair os proletários na miséria como também arruína um grande número de burgueses; que, portanto, ou a própria grande indústria tem de ser completamente abandonada - o que é uma absoluta impossibilidade -, ou então ela torna absolutamente necessária uma organização totalmente nova da sociedade, na qual já não são os fabricantes individuais, em concorrência entre si, mas toda a sociedade, de acordo com um plano estabelecido e segundo as necessidades de todos, quem dirige a produção industrial (ENGELS, 1847, in: Princípios Básicos do Comunismo). 
Para Engels, a revolução industrial levou à diminuição do tempo de produção e do custo de produção das mercadorias, uma superprodução de mercadorias que levam à crise comercial com crises inerentes ao sistema.

O autor percebeu a periodicidade das crises capitalistas e que estas levariam à miséria, tanto os proletários, como os burgueses.

A grande indústria criou, com a máquina a vapor e as outras máquinas, os meios para multiplicar até ao infinito a produção industrial num tempo curto e com poucos custos. Sendo a produção tão fácil, a livre concorrência necessariamente decorrente desta grande indústria muito depressa assumiu um caráter extremamente intenso; um grande número de capitalistas lançou-se na indústria e, a breve trecho, produzia-se mais do que podia ser consumido. A consequência disso foi que as mercadorias fabricadas não podiam ser vendidas e sobreveio uma chamada crise comercial. As fábricas tiveram de ficar paradas, os fabricantes caíram na bancarrota e os operários ficaram sem pão. Por toda a parte sobreveio a maior miséria. Depois de algum tempo foram-se vendendo os produtos em excesso, as fábricas voltaram a trabalhar, o salário subiu e, pouco a pouco, os negócios passaram a ir melhor do que nunca. Mas não por muito tempo, já que de novo voltaram a produzir-se mercadorias em excesso e sobreveio uma nova crise, que seguiu precisamente o mesmo curso que a anterior (ENGELS, 1847, in: Princípios Básicos do Comunismo).

Assim, desde o começo deste século, a situação da indústria tem oscilado continuamente entre épocas de prosperidade e épocas de crise, e quase regularmente, de cinco em cinco anos, ou de sete em sete anos, sobreveio uma destas crises, de todas as vezes conjugada com a maior miséria dos operários, com uma agitação revolucionária geral e com o maior perigo para toda a ordem vigente (ENGELS, 1847, in: Princípios Básicos do Comunismo).

Para o autor, todos os males decorrentes da livre concorrência, da superprodução de mercadorias, das crises que se repetiam regularmente e da miséria que as acompanhavam "são de imputar à ordem social que já não se adequa às condições existentes, “[...] que já existem os meios para eliminar completamente estes males por meio de uma nova ordem social” (ENGELS, 1847, in: Princípios Básicos do Comunismo). Por isso a temporalidade imanente das relações sociais de produção capitalistas já presente no texto.

Mas para o autor qual seria essa nova ordem social? Uma sociedade na qual fazer-se "explorar todos esses ramos da produção por toda a sociedade, isto é, por conta da comunidade, segundo um plano da comunidade e com a participação de todos os membros da sociedade”. Uma ordem social que abolirá a concorrência e estabelecerá no seu lugar a associação.

Para Engels, a propriedade privada deveria ser abolida e, no seu lugar, estabelecer-se-ia a utilização comum de todos os instrumentos de produção e a repartição de todos os produtos segundo acordo comum, ou a chamada comunidade dos bens.

No texto a supressão da propriedade privada é a expressão fundamental desta transformação da ordem social e, portanto, deveria ser a reivindicação principal dos comunistas.

Note-se que nesse documento, a nova ordem social vinha com a autodestruição do sistema. No Manifesto esta passagem será via a ação organizada do proletariado como classe revolucionária. 
Mas conforme o autor "somente poderá abolir a propriedade privada quando estiver criada a massa de meios de produção necessária para isso" (ENGELS, 1847, in: Princípios Básicos do Comunismo).

Ela estabelecerá, antes do mais, uma Constituição democrática do Estado, e com ela, direta ou indiretamente, o domínio político do proletariado.[...] A democracia seria totalmente inútil para o proletariado se ela não fosse utilizada imediatamente como meio para a obtenção de outras medidas que ataquem diretamente a propriedade privada e assegurem a existência do proletariado (ENGELS, 1847, in: Princípios Básicos do Comunismo).

Engels também já relacionava dialeticamente a generalização planetária das relações mercantis à internacionalização do mercado e à interdependência do sistema. E como isso a internacionalização do proletariado, a luta de classes e sua libertação: (i) ao processo internacional de produção; (ii) à determinação sócio histórica do caráter internacional da revolução e; (iii) à luta como permanente.

Seguindo sua linha de pensamento, a revolução não poderia ocorrer em apenas um país porque a grande indústria estava criando um mercado mundial que arrastava para si e ligava todos os povos da terra numa interdependência entre os povos. Assim, à medida que as relações mercantis iam se generalizando em cada país, avançava na mesma medida a constituição de duas classes fundamentais capitalista e proletário - e a luta entre elas. Para ele, uma revolução que se desenvolveria mais rápido ou lentamente a depender do estágio de desenvolvimento das forças produtivas e acumulação. Mais rápido tanto mais

[...] possuir uma indústria mais avançada, uma maior riqueza, uma massa mais significativa de forças produtivas [...]. Ela terá igualmente uma repercussão significativa nos restantes países do mundo, transformará totalmente e acelerará muito o seu atual modo de desenvolvimento. Ela é uma revolução universal e terá, portanto, também um âmbito universal (ENGELS, 1847, in: Princípios Básicos do Comunismo).

\section{A negação de Engels acerca da paternidade das ideias fundamentais contidas no Manifesto Comunista}

Foi o próprio Engels quem sugeriu a substituição dos princípios pelo Manifesto de forma a integrar os elementos históricos que o comunismo não continha:

[...] sacrifica de saída as 25 perguntas e respostas por uma exposição histórica [...] quanto ao desenvolvimento das ideias, os dois documentos coincidem inteiramente [...] o manifesto não contém uma única ideia que Marx e Engels já não tivessem desenvolvido anteriormente. Ele não revela nada, apenas concentra a concepção de mundo de seus autores (COGGIOLA, 2010, p. 26).

Entretanto, Engels reconheceu a paternidade de Marx sobre as "ideias fundamentais" contidas no Manifesto. Em 1883, após o falecimento de Marx, Engels, em uma homenagem ao companheiro Marx, afirmou que a proposição fundamental do Manifesto pertence única e exclusivamente a Marx:

A ideia fundamental que percorre todo o Manifesto é que, em cada época histórica, a produção econômica e a estrutura social que dela necessariamente decorre, constituem a base da história política e intelectual dessa época; que consequentemente (desde a dissolução do regime primitivo da propriedade comum da terra)toda História tem sido a história de luta de classe, da luta entre explorados e exploradores, entre as classes 
dominadas e as dominantes nos vários estágios da evolução social; que essa luta, porém, atingir um ponto em que a classe oprimida e explorada (o proletário) não pode mais libertar-se da classe que a explora e oprime (a burguesia) sem que, ao mesmo tempo, liberte para sempre toda a sociedade da exploração, da opressão e da luta de classes este pensamento fundamental pertence única e exclusivamente a Marx. (ENGELS, 2010b, p. 74. In: Prefácio à edição de alemã de 1883).

Em 1888, novamente Engels declarou que “[...] a proposição fundamental do manifesto pertente à Marx [..]” (ENGELS, 2010b, p. 78. In: Prefácio à edição de inglesa de 1888). Afirmando que, apesar dele e Marx já estivessem elaborando essa ideia vários anos antes 1848, em 1845, Marx tinha exposto tal ideia para ele como escrito no Manifesto e no Prefácio à edição inglesa de 1888.

Para Engels, qual seria a proposição fundamental ou ideias fundamentais apresentadas por Marx? A paternidade de Marx sobre o Manifesto foi trazer o caráter científico da história - que a produção econômica e a estrutura social de cada época (relações de produção e nela a luta de classes) constituem a base da história política e intelectual desse.

Em junho 1846, no texto A Ideologia Alemã, Marx e Engels, num esforço teórico grande, lançaram as bases da concepção científica da história, o materialismo histórico. Parar Marx e Engels à filosofia alemã da época, como ideologia, via os homens e as relações sociais invertidas, "de cabeça para baixo”. Naquele momento os autores defendiam que não é consciência que determina a vida, como construído pela ideologia alemã, mas a vida que determina a consciência. Uma das premissas de partida dos autores foi que:

[...] toda a história humana é, naturalmente, a existência de indivíduos humanos vivos. O primeiro fato a constatar é, pois, a organização corporal desses indivíduos e, por meio dela, sua relação dada com o restante da natureza. Naturalmente não podemos abordar aqui, nem na constituição física dos homens, nem as condições naturais geológicas, hidrográficas, climáticas e outras condições já encontradas pelos homens. Toda historiografia deve partir desses fundamentos naturais e da sua modificação pela ação dos homens no decorrer da história. [O homem ao] produzir os seus meios de vida, os homens produzem, indiretamente, a sua própria vida material.

O modo pelo qual os homens produzem seus meios de vida depende, antes de tudo, da própria constituição dos meios de vida já encontrados e que eles têm de reproduzir [...] o que os indivíduos são, portanto, depende das condições materiais da sua produção (MARX, ENGELS, 2007, p. 87).

Tavares (2015, p.164) qualificou Engels como gentil em sua afirmação de 1886, de que ele seria o "segundo violino no que podemos considerar a ontologia do marxismo":

Que me permitam aqui uma explicação pessoal. Recentemente, por diversas vezes, temse feito alusão ao papel que eu teria desempenhado na elaboração dessa teoria, e é por isso que não posso dispensar de dizer algumas palavras para clarificar esse ponto. Eu não posso negar, antes e durante a minha colaboração de 40 anos com Marx, certo contributo tanto na elaboração como, sobretudo, no desenvolvimento da teoria. Mas a grande maioria das ideias diretrizes fundamentais, particularmente no domínio econômico e histórico, e especialmente na sua formulação definitiva, rigorosa, são obra de Marx. A minha contribuição - talvez com a exceção de alguns ramos especiais -, Marx tê-la-ia muito bem dispensado. Mas o que Marx fez eu não poderia ter feito. Marx ultrapassou-nos a todos, via longe, mais ampla e rapidamente que todos nós. Marx era um gênio. Nós, no máximo, seremos talentosos. Sem ele a teoria estaria longe de ser o que é. É pois justamente que ela tem o seu nome. (ENGELS, 1976 apud TAVARES, 2015, p.164). 


\section{Considerações}

Desconhecemos na trajetória político-teórica de Engels a argumentação ou defesa de seu papel na construção da teoria marxista, ou reivindicação de ideias contidas na teoria de Marx. Ao contrário, sempre se mostrou preocupado em levar o pensamento de Marx na sua ortodoxia, afirmando a autoria e a genialidade do autor em seus escritos, sejam em seus textos de autoria individual ou de produção conjunta com Marx, ou na organização dos escritos de Marx após seu falecimento, como pode ser percebido na organização dos Volumes II e III de O Capital.

Apesar de Engels ter reconhecido em 1883, após o falecimento de Marx, a paternidade do amigo sobre as "ideias fundamentais" contidas no Manifesto - que a proposição fundamental do Manifesto pertence única e exclusivamente a Marx - este trabalho parte do pressuposto que sua participação no Manifesto Comunista foi maior que a colocada pelo próprio autor.

No texto, Princípios do Comunismo, Engels trabalhou tanto (i) categorias desenvolvidas conjuntamente com Marx anos anteriores; (ii) como categorias que ainda não tinham sido desenvolvidas por Marx e que foram para o Manifesto; (iii) além de categorias germinais que, posteriormente, foram aprofundadas por Marx dialeticamente na Crítica da Economia, em especial em sua teoria do valor trabalho.

No texto, Engels definiu o que seria o comunismo; distinguiu proletariado de capitalistas, escravo de proletário, servo de proletário, operário manufatureiro de proletário; articulou dialeticamente as consequências imediatas entre a revolução industrial e a divisão da sociedade em burgueses e proletários; trouxe o papel revolucionário da burguesia como consequência das relações de produção. Todas as categorias apreendidas e fundamentadas nas relações sociais de produção historicamente constituídas. O autor também trouxe a temporalidade imanente das relações sociais de produção capitalista e suas contradições sociais fundadas na natureza das relações sociais de produção capitalistas - o crescimento do proletariado, o grilhão das crises de superprodução e o desencontro entre produção a apropriação capitalista. Através de apreensão científica da história, Engels articulou o desenvolvimento das relações sociais de produção ao caráter internacional da revolução e da luta como permanente e que não seria possível abolir a propriedade privada de um só golpe.

Quase a totalidade dos princípios do comunismo elaborados por Engels em 1847 foram, de alguma forma, incorporados ao documento.

Chegamos ao seguinte ponto, Engels e Marx, um encontro entre dois companheiros de luta que, conjuntamente e dialeticamente se conformavam teoricamente e politicamente, transformando-se.

\section{Referências:}

CALAS, Raoul. O cenário do Manifesto Comunista. In: Problemas - Revista Mensal de Cultura Política, $\mathrm{n}^{\circ} 7$ - Fevereiro de 1948. Disponível em: < https://www.marxists.org/portugues/tematica/rev prob/07/manifesto.htm>. Acesso em 27 de jul. de 2020. 
CARCANHOLO, Reinaldo A. (Org.). Capital: Essência e aparência. São Paulo: Expressão Popular, 2011. (Vol. 1).

ENGELS, Friedrich. Princípios Básicos do Comunismo e outros textos. In: Estudos Vermelhos. Edição do Kindle. Sem ano.

ENGELS, Friedrich . Esboço de uma crítica da economia política. In: Revista Temas de Ciências Humanas. São Paulo, Editora Ciências Humanas, n. 5, pp. 1-2, 1979.

ENGELS, Friedrich. Do socialismo utópico ao socialismo científico. 6. ed. São Paulo: Global Editora: 1984.

ENGELS, Friedrich. Prefácio à edição de alemã de 1883. In: MARX, Karl; ENGELS, Friedrich. Manifesto Comunista. São Paulo: Boitempo, 2010a. (Coleção Marx-Engels).

ENGELS, Friedrich. Prefácio à edição de inglesa de 1888. In: MARX, Karl; ENGELS, Friedrich. Manifesto Comunista. São Paulo: Boitempo, 2010b. (Coleção Marx-Engels).

COGGIOLA, Osvaldo. 150 do Manifesto Comunista. In: MARX; ENGELS. Manifesto Comunista. São Paulo : Boitempo, 2010.

GORENDER, Jacob. O Manifesto do Partido Comunista. Um Documento Datado e Não Datado. mudanças do capitalismo contemporâneo. Revista Lutas Sociais, $\mathrm{n}^{\circ}$ 4, 1998. Disponível em: http://revistas.pucsp.br/ls/article/view/18866/14019>. Acesso em 16 de set. de 2020.

LÖWY, Michel. Prefácio. In: MARX, Karl; ENGELS, Friedrich. As lutas de classes na Alemanha. São Paulo: Boitempo, 2010 (Coleção Marx-Engels).

MARX, Karl. O Capital: crítica da economia política: Livro III: o processo global de produção capitalista. Trad. de Rubens Enderle. São Paulo: Boitempo, 2017. (Coleção Marx-Engels).

MARX, Karl. Glosas críticas e marginais ao artigo "O rei da Prússia e a reforma social: de um prussiano”. São Paulo: Expressão Popular, 2010a.

MARX, Karl. Sobre a questão judaica. Prefácio: Daniel Bensaïd. São Paulo, Boitempo, 2010b. (Coleção Marx-Engels).

MARX, Karl. Manuscritos econômicos-filosóficos. São Paulo: Boitempo, 2010c. (Coleção MarxEngels).

MARX, Karl. Trabalho assalariado e capital \& salário, preço e lucro. São Paulo: Expressão Popular, 2010d.

MARX, Karl. O Capital: crítica da economia política: Livro I: o processo de produção do capital. Trad. de Rubens Enderle. São Paulo: Boitempo, 2013. (Coleção Marx-Engels).

MARX, Karl. O Capital: crítica da economia política: Livro III: o processo global de produção capitalista. Trad. de Rubens Enderle. São Paulo: Boitempo, 2017. (Coleção Marx-Engels).

MARX, Karl; ENGELS, Friedrich. A ideologia alemã. São Paulo: Boitempo, 2007. (Coleção MarxEngels).

MARX, Karl; ENGELS, Friedrich. Prefácio à edição de alemã de 1872. In: MARX, Karl; ENGELS, Friedrich. Manifesto Comunista. São Paulo: Boitempo, 2010. (Coleção Marx-Engels).

SAAD FILHO, Alfredo Antônio. O valor de Marx. Campinas : Unicamp, 2011.

TAVERES, Claudino João. Friedrich Engels e a pedra filosofal da crítica da economia política. In: Verinotio - Revista on-line de Filosofia e Ciências Humanas, n. 20, Ano X, out de 2015. Disponível em: <http://www.verinotio.org/sistema/index.php/verinotio/article/view/217). Acesso em de set. de 2020 
${ }^{1}$ Professora do magistério superior da Universidade Federal do Tocantins em exercício provisório na Universidade Federal do Maranhão, Departamento de Serviço Social. Graduação em Serviço Social pela Universidade Federal do Pará (2007), mestrado em Serviço Social pela Universidade Federal do Pará (2010) e doutorado em Política Social pela Universidade de Brasília (2020). 2. ${ }^{a}$ líder do Grupo de Estudos e Pesquisas em Trabalho, Práxis e Questão Social e pesquisadora no Núcleo Estudos no Brasil Contemporâneo (NEBC/CEAM/UnB). Plataforma Lattes: ORCID: http://orcid.org/0000-0002-5770-7803 E-mail: raquelsabara@yahoo.com.br

2 No texto, Manuscritos econômico-filosóficos de 1844, Marx ao discutir o salário do trabalho e o ganho do capital, ainda não diferenciava trabalho de força de trabalho, nem valor da força de trabalho de preço da força de trabalho. Isso só veio ocorrer em um estágio mais avançado da crítica da economia política. Em o Livro I de O Capital, Marx fez a seguinte diferenciação: "No mercado, o que se contrapõe diretamente ao possuidor de dinheiro não é, na realidade, o trabalho, mas o trabalhador." (MARX, 2013, p. 606), vendendo a sua força de trabalho. Neste sentido, ele não vende o trabalho, mas sim, sua força de trabalho.

${ }^{3}$ No Manifesto Comunista o capital é “ poder de governo [...] sobre o trabalho e seus produtos [...] é trabalho armazenado" (MARX; ENGELS, 2010, p. 40).

4 “[...] o valor é uma relação social de produção ou, em termos quantitativos, é o tempo de trabalho socialmente necessário para reproduzir cada tipo de mercadoria. Ele também pode ser visto como a expressão monetária desse tempo de trabalho como preço direto, preço de produção ou preço de mercado" (SAAD, 2011, p. 13). Conforme Carcanholo (2011), o valor é "[...] uma propriedade de uma característica intrínseca de cada mercadoria, propriedade essa que é social (não natural) e que consiste no poder de compra, no poder de atração que possui essa mercadoria sobre as demais e que permitem que ela tenha aqueles valores de troca determinados não outros menores ou maiores. Esse poder de compra está relacionado, numa primeira análise, à riqueza mercantil que a sociedade reconhece na sua existência (a quantidade de trabalho socialmente necessário para produzi-la). É aí que fica determinado que a magnitude do valor é a magnitude da riqueza mercantil que foi produzida pelo trabalho social, pelo esforço produtivo da sociedade, desviado eventualmente para outros fins" (CARCANHOLO, 2011, p. 14).

5 Tempo socialmente necessário de produção de uma dada mercadoria. 